\title{
A água, a lei, a política...e o meio ambiente*
}

EVERTON VIEIRA VARGAS*

Em um país com a riqueza natural do Brasil, a publicação de obras relacionadas à sua proteção e utilização deveria ser sempre cercada de interesse por parte da mídia, da comunidade acadêmica e das pessoas que têm responsabilidades na área de meio ambiente e desenvolvimento. Infelizmente ainda estamos longe dessa situação, mas a publicação do livro A água, a lei, a política...e o meio ambiente, do professor Christian Guy Caubet, da Universidade Federal de Santa Catarina, nos dá motivos para sermos otimistas sobre as reflexões a respeito da importância estratégica dos recursos naturais e da sua conservação e usos sustentável no Brasil. Aqui, a discussão sobre o meio ambiente tem historicamente ecoado preocupações e conceitos forâneos. A globalização e a velocidade do fluxo das informaçôes com o advento da internet induzem a uma incorporação, às vezes acrítica, de idéias, valores e propostas que desconhecem a realidade e os desafios do Brasil.

No caso dos recursos hídricos, estar atento ao que eles representam para o desenvolvimento brasileiro é muito importante. Segundo o Plano Nacional de Recursos Hídricos, "cerca de 13,7\% do total mundial de água doce estão disponíveis no Brasil, tornando-o, em termos quantitativos, um dos mais ricos em água doce no mundo."1

\footnotetext{
* CAUBET, Christian Guy. A água, a lei, a política...e o meio ambiente. São Paulo: Ed. Jurua, 2004. 305p. ISBN: 85-362-0590-3

** Diretor do Departamento de Meio Ambiente e Temas Especiais do Ministério das Relações Exteriores. As opiniōes expressadas são de caráter pessoal (everton.vargas@gmail.com).

${ }^{1}$ AGÊNCIA NACIONAL DE ÁGUAS. Plano Nacional de Recursos Hidricos. Vide http://www. ana.gov.br/pnrh_novo/Multimidia_PNRH_ANA/DBR-Cap4.pdf. (acesso em 3/10/2004)
} 
O livro do professor Caubet, começa por contextualizar o uso dessa riqueza em função das deficiências de saneamento e das distorções do acesso à água potável no mundo, apontando para o fato de que “ $40 \%$ da água do planeta são consumidos por $20 \%$ da população que vivem em países desenvolvidos". ${ }^{2}$ Outro aspecto relevante é a desigualdade social e regional existente no Brasil, que condicionam os usos e acentuam os problemas para gestão do recurso água. Recorde-se que os recursos hídricos são responsáveis por mais de 68 milhões de kw de energia elétrica. Isso representa pouco mais de $25 \%$ do potencial dos recursos hídricos brasileiros e $90 \%$ da geração de energia no país. Esses dados mostram a natureza estratégica que os recursos hídricos têm para o Brasil e a responsabilidade que recai sobre a sociedade e sobre os agentes públicos no seu tratamento político e legal tanto no plano nacional quanto internacional.

No livro de Caubet se examina a moldura jurídica que rege os recursos hídricos no Brasil, a partir da Lei no 9.433/1997, que institucionalizou a política nacional de recursos hídricos, até 2002. O autor utiliza em sua análise o que denomina de "metodologia das duas pontas", que considera as normas jurídicas em uma extremidade e a realidade social na outra. É na discussão sobre a adequação do fato jurídico ao fato social que critica a abordagem economicista que perpassa o regime jurídico da água. Para ele, a atribuição de um valor decorrente da escassez de um bem não se justifica em relação à água; a primazia cabe ao enfoque da água como um bem ambiental, ante seu papel na manutenção do equilíbrio ecológico. Caubet defende uma mudança de paradigma no tratamento de elementos como a água e o ar, que realce sua importância para a própria existência da vida. Sua crítica desembocará na conclusão de que, para a legislação vigente, "a água não é um assunto de meio ambiente". Este último e o tecido social seriam "os esquecidos da institucionalização". 3

Esse quadro informa a discussão sobre estudos de casos de aproveitamento dos recursos hídricos, em Santa Catarina, e sobre a jurisprudência dos tribunais. Sobressai na análise a distância entre a disposição legal e os processos decisórios que a interpretam. Caubet é

\footnotetext{
${ }^{2}$ CAUBET, p. 20.

${ }^{3}$ Idem, p. 209 e 215.
} 
um crítico ácido da disciplina legal da participação da sociedade civil nas deliberações sobre a utilização da água. No capítulo sobre "Gestão de águas e cidadania”, sublinha a atenção crescente dos organismos internacionais e empresas transnacionais à questão da água e a ênfase das declaraçōes multilaterais sobre a participação da sociedade nas decisões. A avaliação do autor é que os Comitês de Bacia, previstos na legislação, não asseguram uma participação adequada da sociedade.

A abordagem do caso da instalação da usina de aço da multinacional francesa Arcelor, em São Francisco do Su, levanta a questão do interesse internacional pelo potencial hídrico brasileiro. Esse interesse é sempre levantado quando se fala da importância da água como recurso finito e do potencial do Brasil. Tal discussão merece uma abordagem mais aprofundada por parte daqueles que se preocupam com os recursos naturais no plano internacional. No caso da água, procura-se estabelecer um paralelo entre ela e o petróleo, descurando-se que, no caso da primeira, os interesses econômicos podem ser orientados à instalação de unidades de produção em países em desenvolvimento com grande potencial hídrico e uma legislação ambiental menos rígida.

Outro caso interessante que aborda é o projeto de transposição das águas do rio São Francisco. Este é certamente um dos projetos mais antigos da história do Brasil e que ganha relevo ante o alegado potencial da irrigação para atender à área mais carente do Brasil: o Polígono das Secas. O recorte temporal feito pelo autor para o conjunto da obra limita a análise ao projeto debatido no governo Fernando Henrique Cardoso que foi abandonado ante a rejeição da população e a crise de escassez de água de 2001. O exame da transposição do São Francisco pelo autor pode ser útil para os que hoje se debruçam sobre a retomada do empreendimento. Note-se, porém, que não obstante sua posição de princípio em favor do enfoque ambiental, Caubet reconhece a importância dos usos econômicos das águas do São Francisco, especialmente para a produção de energia elétrica e a irrigação.

No exame de casos, aborda Caubet a globalização e suas repercussóes sobre a vida do cidadão. É um aspecto que, não raro, passa despercebido nas discussões sobre o uso dos recursos naturais. Independente da opinião que se possa ter sobre a posição crítica assumida por Caubet quanto à falta de envolvimento da sociedade nas decisões, o fato é que a sociedade 
brasileira começa a ficar mais atenta aos impactos que decisões no plano global podem ter para a inserção do país no cenário internacional ou para a melhoria do bem estar da população. Exemplo disso é a repercussão das barreiras erguidas no exterior a produtos brasileiros.

A importância dos recursos naturais, principalmente aqueles que são abundantes no Brasil, como a água e a biodiversidade, requerem ser tratados como estratégicos para o desenvolvimento nacional. Eles têm uma dupla face: são bens com inegável importância econômica, mas também são elementos indispensáveis para o equilíbrio dos ecossistemas. Ainda que se possa discordar das opinióes nele emitidas, o livro do professor Caubet reúne aspectos práticos a consideraçóes mais abrangentes da questão ambiental. É uma contribuição ao pensamento sobre meio ambiente e sobre sua relevância, inclusive no que tange ao acesso à informação e à participação nos processos decisórios, para o desenvolvimento sustentável no país.

Recebido em 19 de outubro de 2004 Aprovado em 5 de dezembro de 2004 